\title{
MAPPING THE DIVIDE BETWEEN EDUCATION AND CULTURAL MANAGEMENET Transformations in the process of sustainability*
}

\author{
Teresa Tipton \\ Anglo-American University, Prague
}

\begin{abstract}
Analyzing cultural sector reports and initiatives in Portugal in relationship to recent reductions in cultural funding, this paper critiques the divide between discourses for knowledge economy development, sustainability, the educational preparation for art and cultural managers and its sector employment. Conjectural discourse is used as a tool to speculate on the basis for a new palimpsest that includes field-based thinking and human development through creativity to integrating cultural development skills into business management programs, and transform cultural decision-making at the EU policy level. Referencing the concepts of umwelten from biologist Jakob von Uexküll, and Human Scale Development from Chilean economist Manfred Max-neef, the paper argues for the benefits of instability and the need for the redesign of management education to integrate culture and skill sets for managers emphasizing creativity. Following upon the work of Max-Neef (1991) and the Dag Hammarskjöld Foundation (2014) investigation of human needs satisfaction through a transdisciplinary approach to structural transformation of economic systems, different educational, policy, and strategic initiatives for cultural development can be developed. By creating epistemological shifts in worldview and strengthening the human capacity for creativity in education, the current miasma in cultural unsustainability can be productively inverted.
\end{abstract}

Keywords: cultural policies, cultural management, umwelten, discourse analysis, education.

\section{CULTURE'S REPORT CARD}

The professional conundrum that faces undergraduate and graduate students in the fields of art education and cultural management today, concerns those who may be leaving their programs of study without a clear idea of what professional opportunities exist for their own cultural sustainability. Evidence of the EU cultural sector's report card indicate that the culture sector took the biggest percentage of cuts in public and private funding across sectors at 34\% (Everett-Green, 2012). With more cuts anticipated (KEA European Affairs, 2010), the sector's cultural operators and enterprises are nevertheless expected to deliver 'smart, sustainable and inclusive growth' (Committee of the Regions and EG Regional Policy of the European Union,

\footnotetext{
* Part of this paper was presented as a keynote address, Informing the Divide Between Education and Cultural Management: Wherefore Art Thou - the ARTS? For FIGAC 2013: Fórum Internacional de Gestão Artística e Cultural, June 6-8, 2013 at Instituto Politécnico de Viana do Castelo; Viano do Castelo, Portugal.
} 
2011) and regenerate themselves with the least amount of funding while justifying the validity of how their funding was used. Following upon the work of Max-Neef (1991) and Dag Hammarskjöld Foundation's investigation of human needs satisfaction through a transdisciplinary approach to structural transformation of economic systems, this paper proposes different educational, policy, and strategic initiatives for cultural development through field-based thinking and the integration of business and cultural education with a strong approach for the development of human creativity. By investing in new forms of culture and investigating how they are distributed, it is also possible to change our worldview about the ecology of sustainability.

Following upon UNESCO's (2001) declaration safeguarding cultural diversity as a defining characteristic of humanity, the UN's Educational, Scientific and Cultural Organization (2005) advocated for the need for the incorporation of culture as an element of strategic development, social cohesion, and freedom of thought, affirming its value in the social, economic, and political dimensions of community development. During the last decade, several organizations and researchers have mapped the strategic role of culture in sustainable economic development, innovation and revitalization internationally (Cooke \& Lazzeretti, 2007; KEA European Affairs, 2006; Organization for Economic Cooperation and Development, 2006; Throsby, 2001); and in Portugal (Mateus, 2010; Fundação Serralves, 2008; Norte 2015, 2006), cultural industries, and creative enterprises, have been diagnosed, envisioned, and strategized for intervention and economic infusion (Norte 2015, 2006; Mateus, 2010). Following the Fundação Serralves's macroeconomic study of creative industries in 2008, the concrete delineation of economic impacts, territorialization, and mechanisms acting upon the cultural sector in Portugal with its characteristics and activities have been assessed regionally (Agrupación Europea de Cooperación Territorial, 2011). With widespread initiatives, networking, and further research challenging public policy and cultural governance to direct attention to actions and their effects to sustainable strategies, such as cultural clusters, creative networks, and the development of the creative city (Costa, 2007), these studies and research reports document many exemplary cases of the creative economy and the synergy between culture and community development. Although these and subsequent reports document the complex interdependence between funding, policy, and a sustainable sector (Agrupación Europea de Cooperación Territorial, 2011), the discourses between these realms in policy and in practice, remain divided.

While the EU reports for cultural and creative industries (CCIs) appears resilient accounting for $3.5 \%$ of EU products and services, and employing $3 \%$ of the EU 
workforce, (6.7 million people) (European Commission, 2014), the irony of new EU requirements for robust policies and documentation of evidence-based cultural contributions, is that before the 2008 financial crisis, the cultural sector including nonindustrial and industrial sectors and in combination with creative sectors, culture becomes a 'creative' input in the production of non-cultural goods. In Portugal, cultural and creative sectors not only outperformed the rest of the economy (KEA European Affairs, 2006), it produced more than its investments; and in the Alto Minho region of Portugal, cultural employment significantly exceeded the EU average. However, without the backing of cultural funding, cultural operators and creative enterprises have declined, making cultural advocacy statements empty of materialization and creating a schism between the goals of educational output for culture and the results of economic input. The situation of educating cultural operators and managers for their enterprises combined with the planned cuts and the uncertainties of the economy, have created another form of crisis, affecting cultural production itself (Rice-Oxley et al., 2012). Around us can be seen a field of economic atrocities in the cultural sector some of which are intentional and some of which have become the collateral damage of not thinking far enough ahead to plan for a different social outcome.

At a time when social cohesion is planned for and debated without the consideration of culture's role in both social cohesion and innovation, the economic antidote to planned catastrophe is more positivism from R\&D in science, ICT technology and the business entrepreneurship sectors, whose economic contributions remain the benchmarks driving EU public and private sector investments. In the evidence of one of the few sectors for which there are no negative externalities (Gama, 2011), this disparity for culture is not just an educational problem, nor is it solely a policy or economy one. Indicators for primary and secondary value for the cultural sector appear to be ignored or missing (KEA European Affairs, 2006) when economic indicators and its measures are only defined statistically and quantified only according to the production of jobs and income, a form of economic hostage-taking. And yet, even in this area, the sector has proven itself. Thus, the lack of recognition of value for public investment in the cultural sector that fairly matches the sector's overall national and EU economic performance in jobs and economic externalities, is a deeper world-view problem. The implications are that if decision-makers worldwide operated by a different paradigm economically, there would be different choices made, that in turn, would lead to different educational and social outcomes. 


\section{REWRITING THE CULTURE OF BUSINESS}

Across the management schools in the EU, undergraduate and graduate curricula are designed for producing business, management and entrepreneurial qualifications for executive positions in a variety of sectors. Most of the user-friendly programs awarding EU master's degrees in management, however, are nearly completely lacking in the integration of applied business skills in cultural management or investment experience in the cultural sector (http://www.mastersportal.eu/). In a recent study of top innovations in management across the EU (Engle et al., 2010), the cases of cultural enterprises themselves were overlooked and the word culture was used to reference business innovation and its climate.

What is overlooked in business management curriculum and why however, is not because of a low level of economic contribution from the cultural sector, nor its creative capacity to guide and inform the development of innovation skills for business. Nor are the cultural rights of the public being ensured (World Commission on Culture and Development, 1998). Rather, this oversight appears to be structural to the worldview of the business sector itself and the criteria for its system of capital development. In this realm, globalization discourses from companies often consider the carrying capacity from localities where extractions and the means of production are presented through sophisticated marketing language; but in real terms, EU production fails to consider the actual social, ecological, and human costs of what the knowledge-economy of business is producing. Beyond apparent global income-producing streams, however, the relationship between value-added data and the unsustainable behavior from the globalized business sector aren't congruent. In a place between logic and informed reason, the knowledge economy is rather producing an economic divide between high business and low culture that reproduces cyclical economic crises globally.

According to the RAND Corporation's research report (McCarthy et al., 2007), the local arts ecology must include a developed infrastructure, support structures, and community contexts in order to develop sustainability. While creativity and innovation are strategies of the EU 2020 campaign (KEA European Affairs, 2010) and the Council of the European Union, they are still not strategically connected to a fully funded and integrated cultural arts education throughout public schooling curriculum and their levels. Rather, the language of creativity and innovation appear to have been appropriated for business as the lynchpin of economic prosperity without the practical means of achieving it educationally. 
As Naomi Klein (2000) warned in the 1980's, marketing professionals hijacked material production in developed countries and influenced its export to global markets in developing countries by selling images and producing logos instead of the actual products themselves. While the current structure of capital has been justified a necessity for an income-based economy, it cannot suture the divide across inequalities that structurally reinforces and reproduces inequality. When we add it all together, the discourses don't come together, the numbers don't match, the thinking is lopsided, and the results of a systematic destabilization in societies and economies is everywhere around us. Elkins (2012) argues however, that the purpose of economics is to find out how to increase human welfare. Common good outcomes like human welfare involves more than the maximization of production and consumption. Welfare has to do with well-being that is physical as well as mental, emotional, social, environmental and spiritual, all of which are elements touched upon by culture.

\section{UMWELTEN AND THE ROLE OF CREATIVE INSTABILITY}

Conjecture as a tool of indeterminacy, helps map and express a particular cultural selflocation and establishes the imaginative possibilities to envision new ones. Whether related to an individual, a nation, or a history, uncertainty is part of a creative process that allows certainty to shift into another position. Looked at from another perspective, the unpredicatable instability from the systematic defunding of the culture and creative field, has inadvertently produced the conditions for exemplary creativity and a capacity for resourceful innovation and self-sustainability that is not produced by income.

Shifting awareness to another kind of field that culture lives in, what the German theoretical biologist Jakob Uexküll wrote about a century ago, called umwelten or umwelt (Bains, 2001), can offer the possibility for a new worldview perspective. Umwelten recognizes that in the case of human organisms, all that the organism is thinking, feeling and how they are behaving, affects the relations with other organisms, and that paying attention to this can mean that one individual can affect the relations of other individuals and organisms, and hence affect environmental change.

In umwelten, the environment is not separated or outside of ourselves; nor is it merely a location where we find ourselves in, but includes the environment of everything that is outside and inside, and both affect each other. Umwelten informs us that internal processes inside of the individual find their codes and manifest simultaneously into the external circles of behavior of the organism in the environment. New ideas find their recognition simultaneously through resonance, creating new codes that are enacted in new social patterns. Considered in this way, people are always interconnected to 
everything seen and unseen as a part of an ecological system, and effect every ecological environment they are in, just by the fact of presence - of being there. While this concept has been developed over the decades between biology and semiotics, its potential for profoundly affecting shifts in perspective is to experiment with it and engage its various aspects for cultural sustainability.

In looking underneath the discourses of wealth production and economic expansion, perhaps it is indeed the moment to recognize as well the cultural and creative community's perceived lacks as benefits which support qualitative protocols and inquire into them and research how creativity works in culture - off of the margins and into unpredictable networks. Here, the cultural sector has produced creative leaders and innovation consultants, cultural creatives and visionaries, well-trained in the fortitude of the abstinence of income.

To look to the world's poorest people for creative ways in which to reinvent ourselves in relationship to resources and their access is not too far from the recommendation of the Chilian economist Manfred Max-Neef (1991), who argues that those who have been displaced and are unequal participants in societies and their economies internationally, demonstrate a kind of creativity to survive that we need to investigate. Max-Neef (1992) theorized that creativity is one of nine basic, human needs that can be satisfied by actions that can address multiple needs at the same time. Recognizing creativity as a basic human need educationally and in policy will shift the emphasis on what economics is for. Education can take charge of the reform of creativity by integrating the agency of creative thinking across subject disciplines and professionalizing programs. By studying the creativity of culture, it could be possible to recognize the umwelten of our current environmental experience, inhabiting the same fragile planet together, and restore the meaning of resource production to achieve individual and collective needs fulfillment.

Creativity is a form of aliveness that contributes to new interpretations of meaning. Engaging in the arts creates the potential for new cultural relationships to form within ourselves and with each other in the world. Today there is a great absence in this lack. Despite all of the great accomplishments and creative inventions in the world, a thinking person can look everywhere around themselves and see a great absence in our social and economic patterns and it is not too far of a stretch to say it is the absence of the presence of an authentic human development, to which only the source cause can be attributed the economic and structural approach to capitalizing education which impoverishes arts and culture, a condition which matches the social attitude, both reinforcing each other. 
Postmodern paradigms have moved the cultural arts from deconstruction to the rewriting of codes that once dictated the nature of reality. The current focus on exploring the terrain of cultural umwelten in which each person, with his or her own thoughts and perceptions develops an understanding of their innate connections with others, is an unfolding, emerging process that leads us to the need to nurture new interdependencies. With the concept of umwelten, we can rewrite the codes of our own imagined and created catastrophes.

\section{HUMAN SCALE DEVELOPMENT}

Supporting a structural transformation in economics is the strategy of developing a resource-based economy. To inspire, empower, and engage a new kind of manager is to shift from income-based to resource-based economics through new models, new strategies, and new ways of thinking about what it means to be an interconnected part of the umwelten of everyday living.

According to Jacque Fresco, developing an alternative vision of what the future could be like and redesigning our cultures requires a higher sense of ethical standards and the enactment of international laws to assure a sustainable global society (http://thevenusproject.com). Jacque Fresco's model for global sustainability, the Venus Project defines a resource economy as

a holistic socio-economic system in which all goods and services are available without the use of money, credits, barter or any other system of debt or servitude. All resources become the common heritage of all of the inhabitants, not just a select few. The premise upon which this system is based is that the Earth is abundant with plentiful resource; our practice of rationing resources through monetary methods is irrelevant and counter productive to our survival (http:www.thevenusproject.com/about/the-venus-project).

Resourceful living represents values that are already present in the cultural sector and can be productively investigated.

Max-Neef (1991) theorized human scale development is the intentional planning for the structural processes of addressing individual and collective needs satisfaction. According to Max-Neef, human scale development is,

focused and based on the satisfaction of fundamental human needs, on the generation of growing levels of self-reliance, and on the construction of organic articulations of people with nature and technology, of global processes with local activity, of the personal with the social, of planning with autonomy, and of civil society with the state (Max-Neef et al., 1991: 8). 
Today, the self-organizing feedback systems for culture look as if it is in a state of system collapse, and the word crisis is repeated like a mantra. However, if we are able to perceive that the cultural and creative sectors are wealthy in resources - rich in talent and creativity, and abundant in the inner resiliency born of an authentic conversation with the creative part of a person that produces the heart of culture, perhaps the practices of art and culture would elicit more respect. In this inner landscape, we are the very wealthy patrons of the soul.

In exploring these wild and weary intersections, the meandering and ever-changing crossroads of an economic crisis whose inner lining is not silver, is a catastrophe of a nature we can only just glimpse. Whether the situation will be worse or better is an inner question each person has to answer for themselves, and to be prepared for their own answers to change. We are not facing a landscape of positivism in the economy around us, but provocative engagement or revolutionary rebellion. Human scale development and creativity are partners in regenerating educational and business practice alike.

Umwelten gives us a very different picture of both economics and patterns of human behavior, allowing for the health of communities and individuals in them to be paid attention to through self-organizing feedback systems. What the individual is thinking as well as doing has its impact on communities. History as a narrative of progress guided by human reason is a minus end game to which culture can contribute a new imaginary and rewrite the blog of the present, creating new visions, empowering each person as equal participants in the same story - our central disciplinary place, with new values, enhancing what culture satisfies. As artists, cultural managers and operators, curators, patrons, scholars and professors, we have the inner riches that have always driven creative acts of one sort or another. The face of the arts, in culture, and culture in the arts, in the world, starts inside the individual. And that is the place education is entrusted with encouraging, and guiding; the part of ourselves that is teleologically noetic.

To sensibly respond to what is happening day-to-day in our communities, as people look for a better position for themselves and their families, hoping to ensure a future sustainability requires a deeper reflection on how the system of exclusions in both education and business have failed not just culture but our societies themselves. Our inner promptings lead us to answer the call to urgency, not as an authority, but willingly, because culture matters and the matters of culture cannot be neglected, as they are now, where university graduates have nothing to say about the great accomplishments of the past because they don't know what they are. This great spirit of 
nothingness, not only occupies the centrality of the social consciousness; it reproduces like a virus and can be found everywhere, even in the remotest parts of the Amazon.

For this reason, the activities of culture and creativity are increasingly necessary, if not essential, for the social transformation of business models and their intersection with education. Stability, growth and jobs in culture require investments in people that our systems of education can support and manage.

\section{CONCLUSION}

Beyond the bright, marketing language that mystifies cultural programs and ourselves in them, what will the outcomes of education be for culture? And what will we, as educable people, contribute to culture's sustainability? In this arena, one can either be a cynic or a rebel, but to be both publically is somewhat dangerous and fraught with disciplinary vertigo.

Culture has a key role in the economic and social recovery, leveraging investment in growth sectors. But it is time for policy makers under public pressure to put culture back into their policy funding and not just its language. This takes strong advocates who can help create an awareness of the umwelten of the present and speak authentically to those who yield their power publically and privately on behalf of common good outcomes that produce human and social well-being structurally. If crisis precedes transformation, as either a destructive or creative force, supporting umwelten in economic planning and policy and foregrounding the importance of human scale development in education, policy, and business, would greatly support the integration of a new cultural worldview. If as educators and culture critics, as scholars and cultural operators, we can plant new visions of what we want to create in our lives, in our communities and ourselves, then let it call us forward and midwife it to appear in the world around us. Supporting umwelten in economic planning and policy, foregrounds the importance of human scale development in education, policy, and business, greatly supporting a new vitality for culture.

Business and managers are partners in this task, for we need structural skills to take visions and make them plans, to think them out and network resources together to constellate ideas through people in places that produce meaningful results over periods of time in places we occupy, go to and experience. In this way, the culture of creativity can take a central role in the future viability of communities and become an active partner in the development of social capital - and invest it into the things that matter in our lives. And if we find that space, it will be because we put ourselves there and choose to be doing what we're doing, not because there is more money to be made but 
because this is what is important and essential, not just to our own lives but for the future of our communities and cultures as well.

\section{REFERENCES}

Agrupación Europea de Cooperación Territorial (2011) Estudo das industrias culturais e creativas en Galicia e o Norte de Portugal. Galicia, PT: Agrupaciön Europea de Cooperatiön Territorial.

Bains, Paul (2001) “Umwelten”, Semiotica. 134 (1/4), 137-167.

Committee of the Regions and EG Regional Policy of the European Union (Eds). (2011, December). Investing in Europe's future: Regions and cities delivering smart, sustainable, and inclusive growth. Open days 2011: Proceedings. European Commision: Enterprise and Industry. Modified February 2012. http://ec.europea.eu/regional policy/conferences/od2011/doc/publi/od2011 proceed ing en.pdf

Costa, Pedro (2007) "Creativity, innovation and territorial agglomeration in cultural activities: the roots of the creative city", in Cooke, P. \& Lazzeretti, L. (Eds.) Creative cities, cultural clusters and local economic development. Cheltenham, UK: Edward Elgar Plublishing Ltd., pp. 183-210.

Dag Hammarskjöld Foundation (2014, October 31) Hidden money, hidden resources: Financing development with transparency. http://www.daghammarskjold.se

Engle, Kai; Diedrichs, Eva; Brunswicker, Sabine et al. (2010) Imp3rove: A European project with impact. 50 success stories on innovation management. Europe INNOVA. European Commission's Directorate General Enterprise and Industry. Luxembourg: European Union. Retrieved from: https://www.improve-innovation.eu/wpcontent/uploads/2010/07/50-Success-Stories-on-InnovationManagement IMPxrove 50 Success Stores web.pdf

Elkins, Paul (Ed.) (2012) The living economy: a new economics in the making. London: Routledge and Kegan Paul. European Commission

European Commision (2014) Creative Europe: Culture for growth and jobs. http://ec.europea.eu/culture/policy/strategic-framework/grwoth-jobs en.htm 
Eurozine (2012, October 12) "Financing cultural journals: A European survey. Eurozine editorial”, in Eurozine. http://www.eurozine.com/articles/2012-09-12-editroialen.html

Everett-Green, Robert (2012, July 17). "Europe grapples with deep culture cuts", in The Globe and Mail. http://www.theglobeandmail.com/arts/europe-grapples-with-deepculture-cuts-article4422489/

Fresco, Jacque (undated) The Venus Project. http://www.thevenusproject.com/en/jacque-fresco.

Fundação Serralves, (2008, July). Estudo macroeconómico desenvolvimento de um cluster de indústrias criativas na região do norte: Relatório final. Porto: Fundação Serralves.

Gama, Manuel (2011). Formação em Teatro e Formação de Públicos. Unpublished MA Dissertation. Viana do Castelo: Escola Superior de Educação, Instituto Politécnico de Viana do Castelo, Portugal.

Instituto Nacional de Estatística (2014, October) Sustainable Development Indicators. http://www.ine.pt/xportal/xmain?xpid=INE\&xpgid=ine dossie idsustentavel\&xlang =en

KEA European Affairs (2010, October) "Final cuts for art and culture in the EU budget", in The Independent's Voice, October 21, 2010. http://www.culturalpolicies.net/web/files/83/en/KEA-Arts cuts en.pdf

KEA European Affairs (2006) The economy of culture in Europe. Directorate-General for Education and Culture, European Commission. Retrieved from http://ec.europa.ed/culture/library/studies/cultural-economy en.pdf

Klein, Naomi (2000) No logo: Taking aim at the brand bullies. Toronto, ON: Vintage Canada.

Linder, Mindy \& Tam, Myra (2009) UNESCO background paper. Prepared for Center for Community Arts and Cultural Policy Research interest group for international cultural policy and administration. CCACP. http://ccacp.uoregon.edu/sites/ccacp.uoregon.edu/files/unesco background paper.p $\underline{\mathrm{df}}$

Mateus, Augusto et al. (2010, Janeiro) O Sector cultural e criativo em Portugal. Estudo para o Ministério da Cultura. Relatório Final. Augusto Mateus \& Associados. 
Max-Neef, Manfred (1992) "Development and human needs", in P. Elkins \& M. MaxNeef (Eds.) Real-Life Economics: Understanding Wealth Creation. London: Routledge, pp. 197-214. http://atwww.alastairmcintosh.com/general/resources/2007Manfred-Max-Neef-Fundamental-Human-Needs.pdf

Max-Neef, Manfred (1991) Human scale development: Conception, applications and further reflections. New York, NY: The Apex Press. Retrieved from www.areanet.org/file.admin/user upload/papers/Max-neef Human Scale development.pdf

McCarthy, Kevin; Ondaatje, Elizabeth Heneghan \& Novak, Jennifer (2007) Arts and culture in the metropolis: Strategies for sustainability. Santa Monica, CA: RAND Corporation. Retrieved from http://www.rand.org/pubs/monographs/MG477

Myerscough, John (1988) The economic importance of the arts in Britain. London: Policy Studies Institute, p. 149

Norte 2015 (2006, Fevereiro) Competitividade de desenvolvimento: Uma visão estratégica. Norte 2015. http://www.norte2015.com.pt

Organization for Economic Cooperation and Development (2006) Competitive cities in the global economy. OECD Territorial review. Paris: OECD Publishing. http://browse.oecdbookshop.org/oecd/pdfs/product/o406041e.pdf

Rice-Oxley, Mark; Torpey, Paul \& Clarke, Sean (2012, August 3) "Culture cuts: where austerity measures are curtailing the arts - map", in The Guardian. http://www.theguardian.com/culture/interactive/2012/aug/03/europe-arts-cutsculture-austerity

Throsby, David (2001) Economics and culture. Cambridge, UK: Cambridge University Press.

UNESCO (2005, October 20) Convention on the protection and promotion of the diversity of cultural expressions 2005. http://portal.unesco.org/en/ev.php$\underline{\mathrm{URL}} \mathrm{ID}=31038 \& \mathrm{URL} \quad \mathrm{DO}=\mathrm{DO}=$ TOPIC\&URL $\quad$ SECTION=201.html

UNESCO (2001, November 2) Universal declaration on cultural diversity. http://portal.unesco.org/en/ev.php-

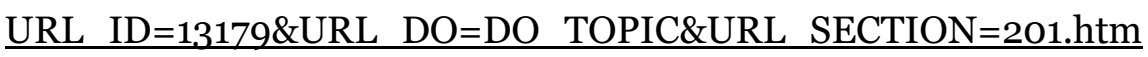

World Commission on Culture and Development (1998) Background document on "Our Creative Diversity" Report of the World Commision on Culture and Development. http://unesdoc.unesco.org/images/o015/001591/159177E.pdf. 


\section{http://www.mastersportal.eu/}

\section{http://thevenusproject.com}

Dr. Teresa M. Tipton is Senior Lecturer in Visual Culture and Contemporary Art at Anglo-American University in Prague, Czech Republic. Her expertise is in visual semiosis, curriculum design, and pedagogy. Her publications focus on the communicative dimensions of contemporary visuality in the development of social knowledge pedagogically. For the past ten years, she has participated in national and international research studies investigating the influence of mass media inscriptions on schema development, identity, and their discourses; the use of digital arts in citizenship education; and strategies for school-to-museum programs with contemporary art. teresa.tipton@aauni.edu 